University of Nebraska - Lincoln

DigitalCommons@University of Nebraska - Lincoln

Virology Papers

Virology, Nebraska Center for

August 1986

\title{
Production of Acquired Immunodeficiency Syndrome-Associated Retrovirus in Human and Nonhuman Cells Transfected with an Infectious Molecular Clone
}

\author{
Akio Adachi \\ National Institute of Allergy and Infectious Diseases, National Institutes of Health, Bethesda, Maryland \\ Howard E. Gendelman \\ National Institute of Allergy and Infectious Diseases, National Institutes of Health, Bethesda, Maryland \\ Scott Koenig \\ National Institute of Allergy and Infectious Diseases, National Institutes of Health, Bethesda, Maryland \\ Thomas Folks \\ National Institute of Allergy and Infectious Diseases, National Institutes of Health, Bethesda, Maryland \\ Ronald Willey \\ National Institute of Allergy and Infectious Diseases, National Institutes of Health, Bethesda, Maryland \\ See next page for additional authors
}

Follow this and additional works at: https://digitalcommons.unl.edu/virologypub

Part of the Virology Commons

Adachi, Akio; Gendelman, Howard E.; Koenig, Scott; Folks, Thomas; Willey, Ronald; Rabson, Arnold; and Martin, Malcom A., "Production of Acquired Immunodeficiency Syndrome-Associated Retrovirus in Human and Nonhuman Cells Transfected with an Infectious Molecular Clone" (1986). Virology Papers. 87. https://digitalcommons.unl.edu/virologypub/87

This Article is brought to you for free and open access by the Virology, Nebraska Center for at DigitalCommons@University of Nebraska - Lincoln. It has been accepted for inclusion in Virology Papers by an authorized administrator of DigitalCommons@University of Nebraska - Lincoln. 


\section{Authors}

Akio Adachi, Howard E. Gendelman, Scott Koenig, Thomas Folks, Ronald Willey, Arnold Rabson, and Malcom A. Martin 


\title{
Production of Acquired Immunodeficiency Syndrome-Associated Retrovirus in Human and Nonhuman Cells Transfected with an Infectious Molecular Clone
}

\author{
AKIO ADACHI, ${ }^{1 *}$ HOWARD E. GENDELMAN,${ }^{1}$ SCOTT KOENIG,${ }^{2}$ THOMAS FOLKS,${ }^{2}$ RONALD WILLEY, \\ ARNOLD RABSON,${ }^{1}$ AND MALCOLM A. MARTIN ${ }^{1}$ \\ Laboratory of Molecular Microbiology ${ }^{1}$ and Laboratory of Immunoregulation, ${ }^{2}$ National Institute of Allergy and \\ Infectious Diseases, National Institutes of Health, Bethesda, Maryland 20892
}

Received 3 March 1986/Accepted 15 April 1986

\begin{abstract}
We constructed an infectious molecular clone of acquired immunodeficiency syndrome-associated retrovirus. Upon transfection, this clone directed the production of infectious virus particles in a wide variety of cells in addition to human T4 cells. The progeny, infectious virions, were synthesized in mouse, mink, monkey, and several human non-T cell lines, indicating the absence of any intracellular obstacle to viral RNA or protein production or assembly. During the course of these studies, a human colon carcinoma cell line, exquisitely sensitive to DNA transfection, was identified.
\end{abstract}

A group of T-lymphotropic retroviruses (RVs), with a genomic structure characteristic of lentiviruses (34), has been isolated from patients with acquired immunodeficiency syndrome (AIDS), AIDS-related complex, and generalized lymphadenopathy $(2,9,23)$. During its propagation in vitro, the virus selectively infects and ultimately kills the subset of human $T$ lymphocytes exhibiting the OKT4-Leu-3 phenotype $(7,20)$, the same cells that are profoundly affected in individuals suffering from the disease $(14,15)$.

Mechanisms responsible for cell- and species-specific tropism(s) have been studied in a number of retroviral systems. For both avian and murine RVs, restriction affecting the interaction of the viral envelope glycoprotein and a specific cell receptor has been demonstrated repeatedly and is responsible for the unique host range of xenotropic and ecotropic mouse leukemia viruses (for a review, see reference 36). In the murine system, at least, retroviral restriction or tropism may also be determined at a point subsequent to adsorption and penetration. For example, the thymotropism exhibited by many mink cell focus-forming murine leukemia viruses very likely reflects the properties of enhancer elements present within the long terminal repeats of these recombinant murine leukemia viruses (5). Furthermore, $F v-1$ (29) restriction involves the interaction of viral capsid proteins $(18,19,31)$ and certain cell component(s) during the early phase of infection.

In this report, the potential restriction of AIDS RV replication in non-T4 lymphocytes was evaluated. Because the transfection of an infectious molecular clone of the AIDS RV provirus would bypass any barrier imposed by the interaction of virus particles with their receptors, intracellular restriction affecting the expression of viral genes can be readily examined. Cloned AIDS RV DNA was introduced into 3 human lymphoid, 11 human nonlymphoid, and 3 nonhuman cell lines. The progeny, infectious virions, were detected in 14 of the 17 transfected cell lines, indicating the absence of any intracellular obstacle to viral RNA or protein synthesis and assembly.

\footnotetext{
* Corresponding author.
}

\section{MATERIALS AND METHODS}

Cells. The cell lines used in these studies are listed in Table 1. The three human lymphoid cell lines were propagated and maintained in RPMI 1640 medium supplemented with heatinactivated $\left(56^{\circ} \mathrm{C}\right.$ for $\left.30 \mathrm{~min}\right) 10 \%$ fetal calf serum. The adherent cell lines listed in Table 1 were cultured in Dulbecco modified Eagle minimal essential medium containing heat-inactivated $10 \%$ fetal calf serum. Normal human peripheral blood lymphocytes (PBLs) were cryopreserved and stored in liquid nitrogen until needed. Before use, the PBLs were quickly thawed, washed, and prepared for infection as described previously (2).

Construction of an infectious molecular clone. The origin of the NY5 and LAV AIDS RV isolates has been outlined previously $(2,3)$. Molecular clones of integrated NY5 and LAV proviruses were obtained from bacteriophage lambda DNA libraries constructed from EcoRI-restricted preparations of virus-infected PBLs. NY5 proviral DNA, like other North American isolates, contained a single EcoRI site at 5.7 kilobases $(\mathrm{kb})$ and was cloned as two separate restriction fragments containing either 5' or 3' flanking cellular DNA. Integrated NY5 proviruses, cloned in EcoRI-digested $\lambda$ Charon 4A (4), were identified by hybridization to ${ }^{32} \mathrm{P}$ labeled pBenn6, which contains 6.5-kb AIDS RV sequences mapping between 1.7 and $8.2 \mathrm{~kb}(8)$. Molecular clones containing sequences located $3^{\prime}$ to the EcoRI site at $5.7 \mathrm{~kb}$ of LAV proviral DNA were isolated from a $\lambda \mathrm{J} 1$ (28) library after hybridization with ${ }^{32} \mathrm{P}$-labeled pBenn4 (8). The cloned NY5 and LAV proviruses were then transferred to EcoRIdigested pUC18 and subsequently used to construct fulllength clones.

Transfection assays. Nonlymphoid and lymphoid cells were transfected by the calcium phosphate precipitation (16, 37 ) and electroporation (30) techniques, respectively, with $10 \mu \mathrm{g}$ of uncleaved plasmid DNA in each assay. Virus production was monitored in non-T4 cells by cocultivation with $\mathrm{CD}^{+} \mathrm{A} 3.01$ cells $\left(10^{6}\right.$ cells of each type) 2 days after transfection. Reverse transcriptase (RT) assays were carried 
TABLE 1. Cell lines used for transfection

\begin{tabular}{|c|c|c|c|c|}
\hline \multirow{2}{*}{ Cell line } & \multirow{2}{*}{ Description } & \multicolumn{2}{|c|}{$\begin{array}{l}\text { Virus } \\
\text { production }^{a}\end{array}$} & \multirow{2}{*}{$\begin{array}{l}\text { Source or } \\
\text { reference }\end{array}$} \\
\hline & & $\begin{array}{l}\text { Co- } \\
\text { culture }\end{array}$ & $\begin{array}{l}\text { Fil- } \\
\text { trate }\end{array}$ & \\
\hline A3.01 & Human T-cell leukemia & + & + & 8 \\
\hline BJAB & $\begin{array}{l}\text { Human B-cell lympho- } \\
\text { ma }(\mathrm{EBV}-)^{b}\end{array}$ & + & ND & 22 \\
\hline Raji & $\begin{array}{l}\text { Human B-cell lympho- } \\
\text { ma }(\mathrm{EBV}+)^{c}\end{array}$ & - & ND & ATCC CCL86 \\
\hline A-204 & $\begin{array}{l}\text { Human rhabdomyosar- } \\
\text { coma cells }\end{array}$ & + & + & АТСС НТВ82 \\
\hline CHP126 & $\begin{array}{l}\text { Human neuroblastoma } \\
\text { cells }\end{array}$ & - & ND & 1 \\
\hline HMB2 & Human melanoma cells & + & ND & 39 \\
\hline CAPAN-1 & $\begin{array}{l}\text { Human pancreatic car- } \\
\text { cinoma cells }\end{array}$ & + & + & АТСС НТВ79 \\
\hline SK-OV-3 & $\begin{array}{l}\text { Human ovarian carci- } \\
\text { noma cells }\end{array}$ & + & + & АТСС НТВ77 \\
\hline T47D & $\begin{array}{l}\text { Human breast carci- } \\
\text { noma cells }\end{array}$ & - & ND & 39 \\
\hline $\mathrm{CaCO}-2$ & $\begin{array}{l}\text { Human colon carci- } \\
\text { noma cells }\end{array}$ & + & + & АТСС НТВ37 \\
\hline SK-CO-1 & $\begin{array}{l}\text { Human colon carci- } \\
\text { noma cells }\end{array}$ & + & ND & АТСС НТВ39 \\
\hline HT-29 & $\begin{array}{l}\text { Human colon carci- } \\
\text { noma cells }\end{array}$ & ND & + & АТСС НТВ38 \\
\hline SW480 & $\begin{array}{l}\text { Human colon carci- } \\
\text { noma cells }\end{array}$ & ND & + & ATCC CCL228 \\
\hline SW1463 & $\begin{array}{l}\text { Human rectal carci- } \\
\text { noma cells }\end{array}$ & ND & + & ATCC CCL234 \\
\hline Mink & $\begin{array}{l}\text { Mink lung epithelial } \\
\text { cells }\end{array}$ & + & ND & ATCC CCL64 \\
\hline COS-1 & $\begin{array}{l}\text { Monkey kidney cells } \\
\text { transformed by sim- } \\
\text { ian virus } 40\end{array}$ & + & + & 12 \\
\hline NIH $3 \mathrm{~T} 3$ & Mouse fibroblast cells & + & ND & ATCC CCL92 \\
\hline
\end{tabular}

$a+$, Production; - , no production. ND, Not determined.

${ }^{b} \mathrm{EBV}-$, Epstein-Barr virus negative.

' $\mathrm{EBV}+$, Epstein-Barr virus positive.

out at various times after cocultivation as described previously (8).

In situ hybridization. Transfected cell preparations were sedimented onto polylysine-coated glass slides, fixed in periodate-lysine-paraformaldehyde-glutaraldehyde, and pretreated with $\mathrm{HCl}$ and proteinase $\mathrm{K}$ to allow the labeled probe to enter the cells $(10,11)$. Cells were prehybridized in $10 \mathrm{mM}$ Tris ( $\mathrm{pH} 7.4)-2 \times$ standard saline citrate (SSC) $(1 \times \mathrm{SSC}$ is $0.15 \mathrm{M} \mathrm{NaCl}$ plus $0.015 \mathrm{M}$ sodium citrate [pH 7.4])-50\% formamide- $1 \times$ Denhardt solution $(0.02 \%$ polyvinylpyrrolidone, $0.02 \%$ Ficoll [Pharmacia Fine Chemicals, Piscataway, N.J.], $0.02 \%$ bovine serum albumin)-200 $\mu \mathrm{g}$ of yeast tRNA per $\mathrm{ml}$ at $45^{\circ} \mathrm{C}$ for $2 \mathrm{~h}$ and were hybridized in this solution plus $10 \%$ dextran sulfate, $5 \mu \mathrm{M}$ dithiothreitol, and $10^{6} \mathrm{cpm}$ of ${ }^{35} \mathrm{~S}$-labeled AIDS RV RNA in $10-\mu$ l reaction mixtures. Subgenomic viral DNA fragments present in $\mathrm{pB} 1$ (3), pBenn6 (8), pB11 (3), and a recombinant plasmid (pRGB) which contains a $1.35-\mathrm{kb}$ HindIII fragment mapping between 8.25 and $9.6 \mathrm{~kb}$ on the proviral DNA were subcloned into SP6/T7 vectors (Promega Biotec, Madison, Wis.), and the pooled DNAs were transcribed with ${ }^{35} \mathrm{~S}$ labeled UTP (Amersham Corp., Arlington Heights, Ill.). The labeled RNAs were incubated with $40 \mu \mathrm{M} \mathrm{NaHCO} \mathrm{Na}_{3}-60 \mu \mathrm{M}$ $\mathrm{Na}_{2} \mathrm{CO}_{3}$ [pH 10.2] before hybridization to facilitate their entry into cells.
Hybridization was performed at $45^{\circ} \mathrm{C}$ for $8 \mathrm{~h}$. The samples were then washed in $2 \times \mathrm{SSC}$ at $22^{\circ} \mathrm{C}$ for $10 \mathrm{~min}$, with two changes; $2 \times \mathrm{SSC}-0.1 \%$ Triton $\mathrm{X}-100$ at $60^{\circ} \mathrm{C}$ for $30 \mathrm{~min} ; 2 \times$ SSC plus RNase A $(40 \mu \mathrm{g} / \mathrm{ml})$ and RNase $T_{1}(10 \mathrm{U} / \mathrm{ml})$ at $37^{\circ} \mathrm{C}$ for $30 \mathrm{~min}$; and $2 \times \mathrm{SSC}$ at $60^{\circ} \mathrm{C}$ for $10 \mathrm{~min}$. All solutions except those with RNase A contained $5 \mu \mathrm{M}$ dithiothreitol and $1 \mu \mathrm{M}$ EDT A. Autoradiography was performed for 1 to 2 days as described previously (11).

CAT assays. Chloramphenicol acetyltransferase (CAT) assays with pSV2CAT DNA have been described previously (13). The uptake of pSV2CAT DNA into transfected cells was monitored by dot blot hybridization using ${ }^{32} \mathrm{P}$-labeled pUC18 DNA.

\section{RESULTS}

Construction of full-length clones of the AIDS RV provirus. Our previous experience indicated that only a minority of cloned murine leukemia virus proviral DNAs were infectious after their introduction into susceptible cells. Therefore, we decided to take advantage of the single EcoRI site that virtually bisected (located at $5.7 \mathrm{~kb}$ ) the proviruses of North American AIDS RV isolates (3), and we elected to mix and match $5^{\prime}$ and $3^{\prime}$ halves of integrated proviral DNAs that had been obtained from different infected cellular DNA libraries. Representative examples are shown in the top portion of Fig. 1. $\lambda \mathrm{N} 5^{\prime}$ consisted of a 20.2-kb EcoRI fragment in $\lambda$ Charon 4A that was cloned from a library of NY5-infected PBLs. $\lambda \mathrm{L} 3$ and $\lambda \mathrm{L} 4$ were isolated from LAV-infected cellular DNA preparations with a $3^{\prime}$ AIDS RV probe and consisted of 7.5and 13.6-kb EcoRI inserts, respectively, in a $\lambda \mathrm{J} 1$ phage vector. An 8.3-kb BamHI-EcoRI subclone of $\lambda \mathrm{N} 5^{\prime}$ was introduced into $\mathrm{BamHI}-E c o \mathrm{RI}$-digested pUC18 to generate a plasmid designated $\mathrm{pN} 5^{\prime}$. Because $\mathrm{pN} 5^{\prime}$ contained a single EcoRI site, EcoRI fragments containing the $3^{\prime}$ half of the AIDS RV provirus could be readily introduced, thereby generating full-length and potentially infectious constructs. The EcoRI segments from $\lambda \mathrm{L} 3$ (both orientations) and $\lambda \mathrm{L} 4$ were inserted into pN5' (Fig. 1). Of note is the presence of a unique HincIII site at $8.7 \mathrm{~kb}$ in pNL4-3; a HincII site at this position (representing a restriction enzyme site polymorphism in the parental LAV virus stock) had been previously identified in an isolate from Alabama (3).

Infectivity of full-length AIDS RV proviral DNA constructs was monitored after electroporation into A3.01 cells. We have previously reported that the A3.01 cell line is $>95 \%$ Leu- $3^{+}$Leu- $8^{+}$Leu- $1^{+}$and is exquisitely sensitive to AIDS RV infection, exhibiting the same viral cytopathic effect observed in infected PBLs, including cell death (8). Only the pNL4-3 DNA construct was infectious after its introduction into A3.01 cells (Fig. 2). Syncytia were visualized in cultures transfected with pNL4-3 DNA as early as day 9. This was followed by a peak of RT activity on day 16 , as well as by a profound reduction in the number of viable cells. pNL3-2 DNA failed to elicit any cytopathic effect or RT activity after its electroporation into A3.01 cells. Because pNL3-2 contained the same $5^{\prime} 5.7 \mathrm{~kb}$ of AIDS RV sequences present in the infectious plasmid pNL4-3, an alteration affecting viral sequences mapping $3^{\prime}$ to the EcoRI joint most likely explains the loss of biological activity.

Transfection of the infectious molecular clone of the AIDS $\mathbf{R V}$ into nonhuman $T$ cells. Viral infectivity studies indicate that, with few exceptions $(24,27)$, the AIDS RV can only be propagated in the Leu-3-OKT4 helper-inducer subset of human $\mathrm{T}$ lymphocytes. This selective cell tropism most likely reflects the interaction of AIDS RV particles with a 


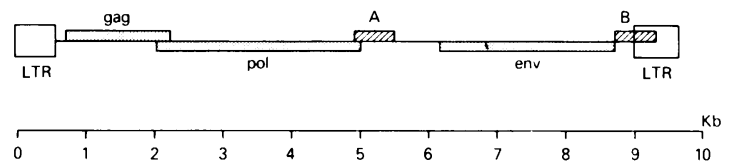

A.

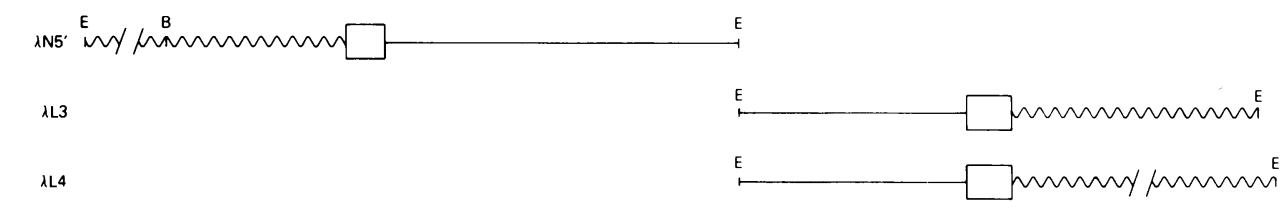

B.

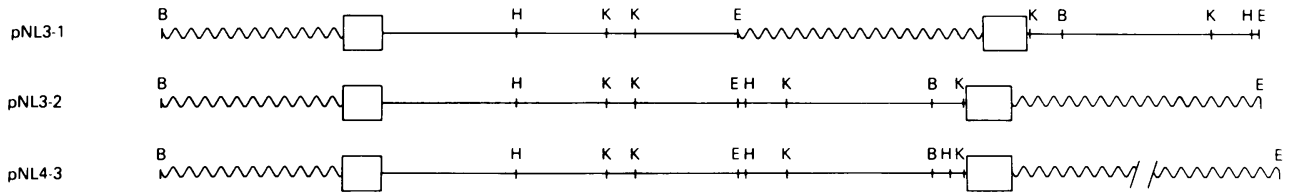

FIG. 1. Construction of full-length clones of AIDS RV. Integrated NY5 and LAV proviruses were cloned in $\lambda$ Charon 4A ( $\lambda$ N5') or $\lambda J 1$ ( $\lambda \mathrm{L} 3$ and $\lambda \mathrm{L} 4$ ), respectively (A). The EcoRI inserts of $\lambda \mathrm{L} 3$ (both orientations) and $\lambda \mathrm{L} 4$ were introduced into the EcoRI site of plasmid pN5' DNA, which contained the BamHI-EcoRI segment from $\lambda \mathrm{N}^{\prime}$ ' (see Materials and Methods) (B). Only inserts are shown. A schematic diagram of AIDS proviral DNA is shown at the top of the figure. Abbreviations: B, BamHI; E, EcoRI; H, HinclI; K, KpnI.

specific receptor(s) $(7,21,26)$ on the surface of $\mathrm{CD}^{+}$ lymphocytes. However, intracellular restriction involving, for example, the activity of viral promoter or enhancer or the assembly of viral proteins and genomic RNA into infectious virions has not been formally ruled out. The existence of such an intracellular block could readily be evaluated with an infectious clone of the AIDS provirus, since the barrier

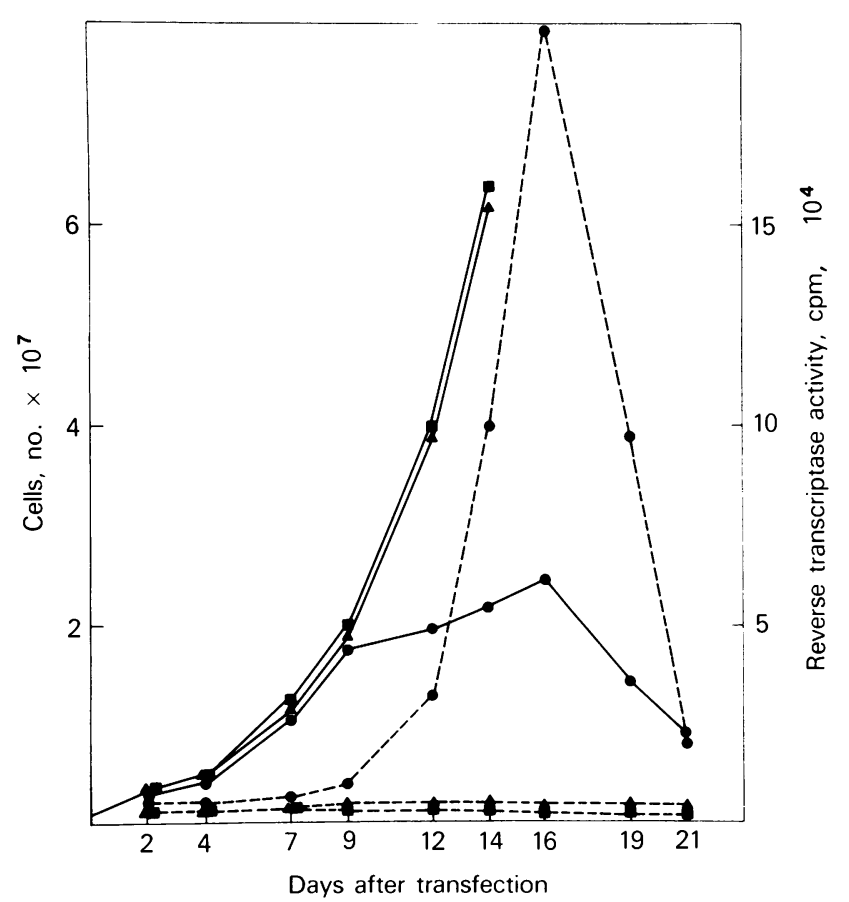

FIG. 2. Kinetics of virus infection after transfection of $A 3.01$

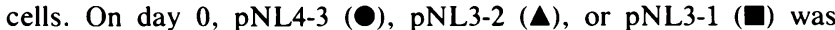
introduced into $\mathrm{A} 3.01$ cells by electroporation, and $10^{6}$ viable cells were placed in culture. The number of viable cells in the culture $(-)$ and RT activity (- -$)$ were monitored on the days indicated. imposed by a specific cell receptor would no longer be a factor.

pNL4-3 DNA was introduced into the 16 non-T cell lines listed in Table 1, which included both human and nonhuman cells. Because none of these transfected cells would be expected to express the putative receptor for the AIDS RV, it seemed very unlikely that progeny, virus particles produced as a result of the initial transfection, would reinfect other cells in the culture. Because insufficient numbers of virions would be generated to be detected directly by the RT assay, $\mathrm{CD}^{+} \mathrm{A} 3.01$ cells were added to the cultures $48 \mathrm{~h}$ after transfection to amplify any virions that appeared. The presence of virus was monitored by RT assays at various times after cocultivation. Of the 16 non-T cell lines, 13 yielded infectious AIDS RV particles as a consequence of transfection with pNL4-3 DNA (Fig. 3 and Table 1). In most cases, the peak of RT activity was detected 14 to 16 days after transfection (12 to 14 days after cocultivation with A3.01 cells); cocultures of COS-1 (monkey) and SK-OV-3 (human ovarian carcinoma) cells exhibited more rapid kinetics of virus production. A repeat of the experiment depicted in Fig. 3 gave similar results. In a parallel experiment that omitted cocultivation with A3.01 cells, no RT was detected. To rule out the possibility that the non-T cell lines might harbor a cryptic lymphotropic virus with RT activity, each was cocultivated with A3.01 cells for 4 weeks; no infectious virus was detected. In addition, when the noninfectious molecular clone of the AIDS RV, pNL3-1, was transfected into each of the cell lines listed in Table 1 , no infectious virions were generated, even after 4 weeks of coculture.

We were interested in ascertaining whether the progeny, virus particles synthesized in non-T cells, entered A3.01 cells by cell-to-cell transfer or whether they budded into the tissue culture medium and subsequently adsorbed to viral receptors on the $\mathrm{CD}^{+}$target cells. Cell-free supernatants obtained from eight (A204, CAPAN-1, CaCO-2, HT-29, SK-OV-3, SW480, SW1463, COS-1) of the cell lines $48 \mathrm{~h}$ after transfection and prepared by filtration of tissue culture medium through $0.45-\mu \mathrm{m}$-pore membranes were used to infect phytohemagglutinin-stimulated PBLs. Infectious AIDS RV was present in all of the supernatants tested, with 


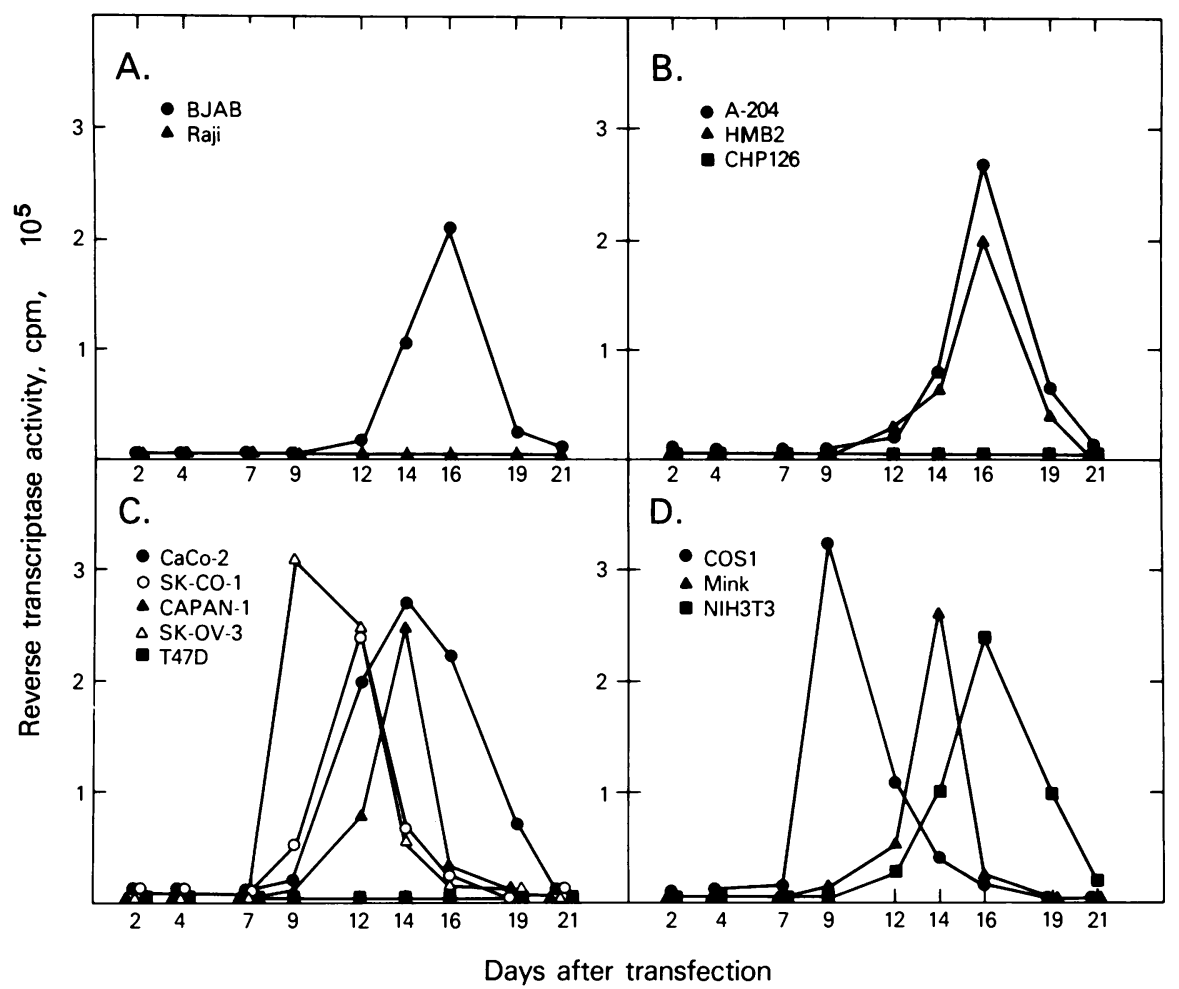

FIG. 3. Kinetics of RT activity in transfected cells cocultivated with A3.01 cells. On day 2 after transfection with the infectious molecular clone pNL4-3, $10^{6}$ cells were cocultured with $10^{6} \mathrm{~A} 3.01$ cells, and RT activity was monitored on the days indicated. See Table 1 for the description of each cell line.

peaks of RT detected 5 to 14 days after infection of the PBLs (Table 1). No virus was detected when the supernatants of mock-infected cultures were examined.

Replication of the AIDS RV in non-T cells was also monitored by in situ hybridization. Viral RNA was readily detected in the A204 rhabdomyosarcoma cell line 2 days after transfection (Fig. 4A). RNase treatment of the transfected cell preparation before hybridization reduced the signal to background levels (zero to two grains per cell). Assuming that five grains above background (seven or more grains per cell) indicated the presence of AIDS RV RNA, approximately $6.7 \%$ of the A204 cells were synthesizing viral RNA $48 \mathrm{~h}$ after transfection. The number of cells expressing viral RNA fell precipitously thereafter, to $0.2 \%$ on day 3 and to 0 (out of $10^{5} \mathrm{~A} 204$ cells examined) on day 7 . The recovery of virus by cocultivation with A3.01 cells on days 2 and 3 but not on day 7 (data not shown) is consistent with these in situ hybridization results. Similar transient expression of AIDS RV RNA was observed in BJAB, SW480, and NIH 3T3 cells transfected with pNL4-3 DNA (data not shown).

Failure to obtain a chronic AIDS RV-producing line. Because the non-T cell lines listed in Table 1 , which synthesized infectious virus particles after transfection, apparently lacked the receptor(s) that would permit the initial burst of virions to spread throughout the culture, the possibility existed that cells continuously producing virus might be isolated from the mass culture of the transfected cells. Therefore, A204 cells were cotransfected with pSV2NEO and pNL4-3 DNAs (in a molar ratio of 1:10, respectively), and G418-resistant cells were selected as described previously (35). In a companion experiment, no G418-resistant clones were obtained from mock-transfected cells. None of the 92 G418-resistant cell clones that were isolated during a 3-week period synthesized infectious AIDS RV after cocultivation with A3.01 cells. This result suggested that the resistant A204 cells, although containing the pSV2NEO gene, harbored either a defective copy or no proviral DNA. This finding also raised the possibility that nonlymphoid cells undergoing productive infection with the AIDS virus may also be killed in the process.

Identification of a human cell line that is exquisitely sensitive to transfection by cloned AIDS RV proviral DNA. During the examination of cell-free filtrates obtained from nonlymphoid cells transfected with the infectious clone of the AIDS provirus, we observed that one of the supernatants contained high levels of RT activity. A more careful evaluation of the human colon carcinoma cell line SW480 revealed that substantial amounts of RT activity were detectable $24 \mathrm{~h}$ posttransfection (Fig. 5); these levels gradually fell to background levels over a 3-week period. When the experiment depicted in Fig. 5 was monitored by in situ hybridization, 25 and $19 \%$ of the transfected SW480 cells were found to be synthesizing viral RNA on days 1 and 2, respectively (Fig. 4B). In comparison with a cloned human $\mathrm{CD}^{+}$lymphocyte cell line (S. Koenig, unpublished data) productively infected with the AIDS RV (Fig. 4D), SW480 cells, expressing viral gene products, contained two to five times more grains.

We considered the possibility that the unique susceptibility of SW480 cells to cloned AIDS RV proviral DNA might represent a more global sensitivity to DNA transfection. Therefore, pSV2CAT DNA was introduced into the seven cell lines indicated in Table 2; conversion of chloramphenicol to its acetylated form, as well as DNA uptake, was measured in each case. When normalized for DNA uptake, SW480 cells were at least five times more efficient in CAT gene expression than any of the other cells lines examined. 

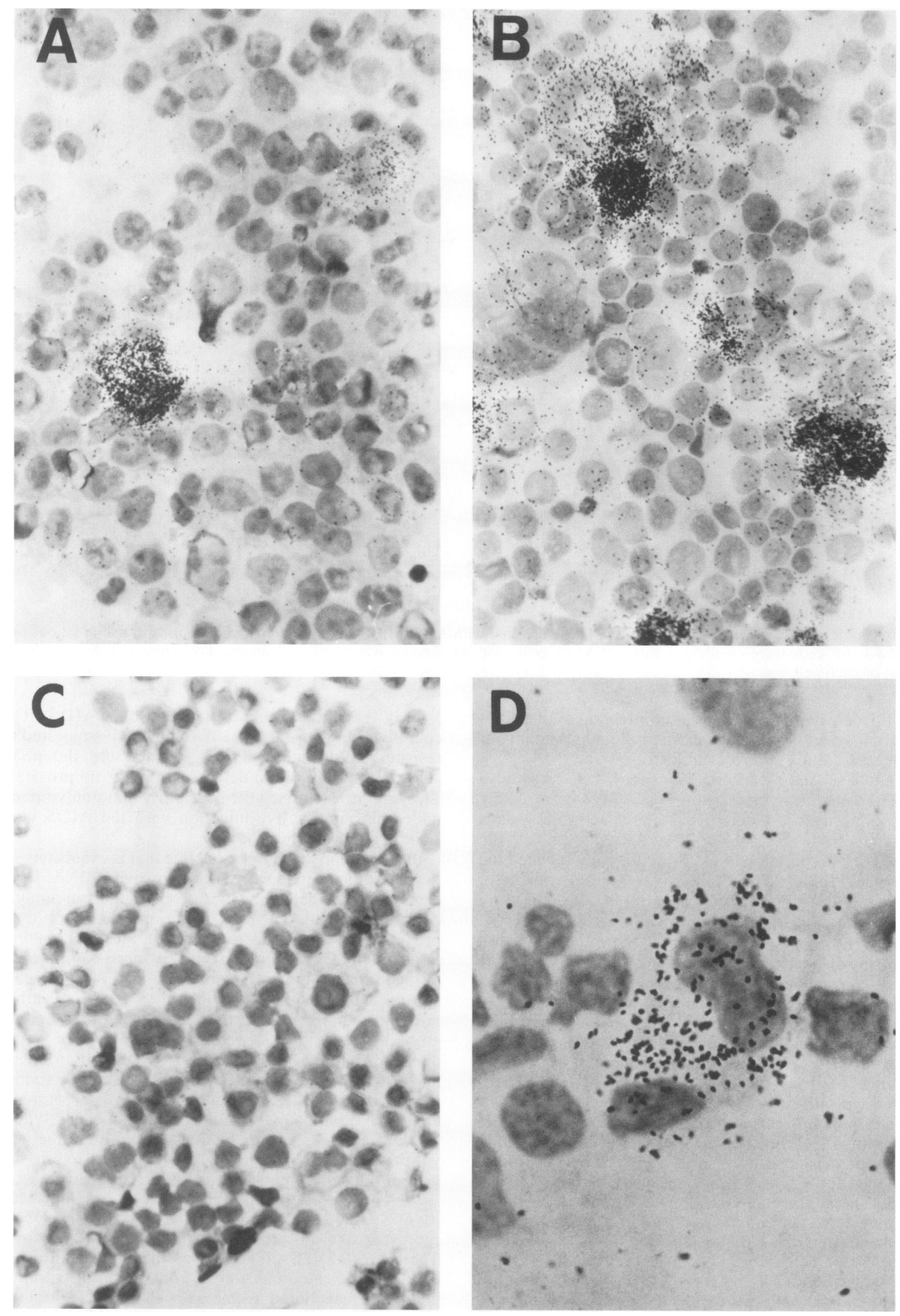

FIG. 4. In situ hybridization of cells transfected with the infectious molecular clone of the AIDS RV. A-204 (A) and SW480 (B) cells were subjected to in situ hybridization $48 \mathrm{~h}$ after transfection with pNL4-3 DNA. Mock-transfected A-204 (C) and LAV-infected CD4 ${ }^{+}$lymphocyte (D) cells are also shown. Magnification in panels $A, B$, and $C, \times 100$; magnification in panel $\mathrm{D}, \times 400$. 


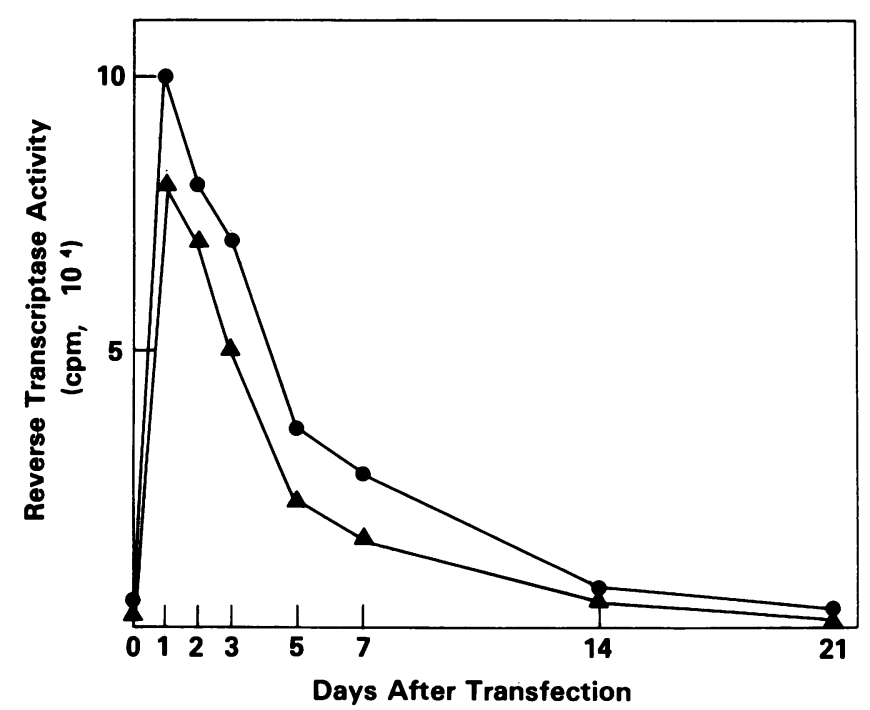

FIG. 5. Kinetics of RT activity in SW480 cells transfected with the infectious clone pNL4-3. On day $0,3 \times 10^{6} \mathrm{SW} 480$ cells were transfected with the infectious clone pNL4-3 by the calcium phosphate precipitation method, and RT activity in the tissue culture medium was monitored on the days indicated. $\boldsymbol{O}$ and $\Delta$ indicate the results of two independent experiments.

\section{DISCUSSION}

A major conclusion of our experiments involving the transfection of an infectious molecular clone of the AIDS virus into several different cell lines is that the interaction of AIDS RV particles with their receptor(s) is clearly the principal determinant of cell tropism. Once this cell surface restriction is negotiated, viral RNA and proteins are synthesized and assembled into infectious and cytopathic virions, irrespective of cell type. Although this result might have been inferred from earlier studies which showed that the AIDS RV-trans-activating determinant functioned in a variety of cell types (33), this is the first report to demonstrate that non- $T$ cells of four different mammalian species are capable of generating infectious virus.

Unlike the situation with the cloned provirus of HTLV-II, which required cotransfection and selection with G418 (6), infectivity with pNL4-3 DNA was observed after its introduction into the $\mathrm{CD}^{+} \mathrm{A} 3.01$ cells without the use of selective pressure. A characteristic feature of transfecting non-T cells with the cloned AIDS RV provirus is the relatively short period (usually up to 7 days) during which progeny are synthesized. This transient production of virions, shown graphically in Fig. 5, most likely reflects the failure of the input DNA to stably integrate into the chromosome of the transfected cells. Concatemers of the cloned viral DNA formed during calcium phosphate precipitation $(16,37)$ may function as pseudointegrated templates for AIDS RV RNA synthesis for relatively brief periods of time, after which they are degraded or otherwise eliminated. Another explanation for the transient expression of virus production after transfection is that cells are killed as a consequence of synthesizing and assembling viral gene products. Proving cell death after the introduction of viral DNA in the systems we used is technically very difficult. At best, about $20 \%$ of transfected cells (in the case of SW480) were synthesizing viral RNA during the first $48 \mathrm{~h}$ after transfection. Unlike experiments with $\mathrm{CD}^{+}$lymphocytes in which virtually all of the cells are killed by waves of newly synthesized virions, nonlymphocytes, dying as a result of a productive virus infection, would be replaced in the monolayer by neighboring cells lacking the receptor(s) for secondary infection by the progeny, AIDS RV particles, and would thereby escape detection. Furthermore, the failure to obtain G418-resistant cells that produce infectious viral particles after cotransfection with pSV2NEO and pNL4-3 DNAs is certainly consistent with the death of nonlymphocytes expressing AIDS RV gene products.

Transfection of the cloned AIDS RV provirus resulted in virus production in 13 of the 16 non-T cells examined. The three instances in which no virus was detected should not be presently viewed as examples of intracellular restriction. Although no virus was generated after the introduction of the infectious clone into Raji cells, a second B-lymphocyte line (BJAB) synthesized replication-competent virions (Table 1). Factors associated with the transfection assay per se, such as the efficiency of DNA uptake, could very likely be responsible for the failure to detect virus particles in all of the cell lines examined.

A by-product of these investigations was the discovery of a human colon carcinoma cell line that was particularly sensitive to transfection. AIDS RV virions were demonstrable in cultures of SW 480 cells 24 h posttransfection, thereby obviating the necessity for cocultivation with $\mathrm{CD}^{+}$target cells. This susceptibility to transfection also extended to non-RV DNAs in experiments involving pSV2CAT DNA. At the present time, we have no explanation for this unique property of SW480 cells. Certainly, the augmented expression of transfected DNA is not due to increased DNA uptake (Table 2), nor is it a characteristic feature of colon carcinoma cells, since four other cell lines (Table 1) failed to exhibit this property of SW480 cells.

We (3) and others $(17,25,32,38)$ have noted that the genomic heterogeneity of the AIDS RV genome affects primarily env gene sequences. Because the studies described in this report demonstrate that the main determinant of cell tropism involves the interaction of the viral envelope and cell receptor(s), it is tempting, from an evolutionary viewpoint, to link env variability to the appearance of the AIDS virus as a human pathogen. Stripped of its capsid and envelope proteins, the cloned viral DNA was expressed as

TABLE 2. Relative CAT activity in cells transfected with pSV2CAT

\begin{tabular}{llrrr}
\hline Cell line & \multicolumn{1}{c}{ Description } & $\begin{array}{r}\text { \% Con- } \\
\text { version }^{a}\end{array}$ & $\begin{array}{c}\text { DNA } \\
\text { uptake }^{b}\end{array}$ & $\begin{array}{c}\text { CAT } \\
\text { activity }^{c}\end{array}$ \\
\hline SW480 & Human colon cells & 83.0 & 1.0 & 100 \\
SK-CO-1 & Human colon cells & 6.8 & 1.2 & 7 \\
SK-OV-3 & Human ovarian cells & 33.8 & 2.0 & 20 \\
CAPAN-1 & Human pancreatic cells & 10.2 & 0.7 & 18 \\
A-204 & Human rhabdomyosarcoma & 3.2 & 1.1 & 4 \\
& $\quad$ cells & 0.5 & 0.2 & 3 \\
HMB2 & Human melanoma cells & 0.7 & 0.8 & 1 \\
NIH 3T3 & Mouse fibroblasts & \\
\hline
\end{tabular}

${ }^{a}$ CAT assays were done with equivalent amounts of protein from each cell lysate ( $100 \mu \mathrm{g}$ per assay). After analysis by ascending thin-layer chromotography, the rates of conversion were determined by scintillation counting. CAT activity of mock-transfected cell lysates was less than $0.1 \%$.

${ }^{b}$ DNA uptake was determined by dot blot hybridization using ${ }^{32}$ P-labeled pUC18 DNA. Membranes were subsequently monitored in a liquid scintillation counter, and DNA uptake was normalized relative to that of SW480 cells. The counts hybridized per minute varied from 2,338 (HMB2) to 29,700 (SK-OV-3); mock-transfected cultures contained less than $200 \mathrm{cpm}$.

c CAT activity was normalized for conversion and DNA uptake relative to that of SW480 cells. 
infectious virus in virtually all cells tested. One could propose that an alteration more profound than is normally observed in the env region of different AIDS RV isolates drastically alters the cell and species target of a progenitor to the AIDS virus. In the process, such a virus could lose its original tropism and assume a new ecological niche: the helper and inducer CD4 ${ }^{+}$lymphocytes of humans.

\section{ACKNOWLEDGMENTS}

We thank B. Johnson for RT assays, T. Bryan for $\lambda$ cloning, and S. Rosenfeld for typing the manuscript.

\section{LITERATURE CITED}

1. Balaban-Malenbaum, G., and F. Gilbert. 1977. Double minute chromosomes and the homogeneously staining regions in chromosomes of a human neuroblastoma cell line. Science 198:739-741.

2. Barre-Sinoussi, F., J. C. Cherman, R. Rey, M. T. Nugeryre, S. Chamaret, J. Gruest, C. Dauget, C. Axler-Blin, F. Vezinet-Brun, C. Rouzioux, W. Rosenbaum, and L. Montagnier. 1983. Isolation of a T-lymphotrophic retrovirus from a patient at risk for acquired immune deficiency syndrome (AIDS). Science 220: 868-871.

3. Benn, S., R. Rutledge, T. Folks, J. Gold, L. Baker, J. McCormic P. Feorino, P. Piot, T. Quinn, and M. Martin. 1985. Genomic heterogeneity of AIDS retroviral isolates from North America and Zaire. Science 230:949-951.

4. Blattner, F. R., G. Williams, A. E. Blechl, K. DennistonThompson, H. E. Farber, L. Furlong, D. J. Grunwald, D. O. Kiefer, D. D. Moore, J. W. Schumm, E. L. Sheldon, and 0. Smithies. 1979. Charon phages: safer derivatives of bacteriophage $\lambda$ for DNA cloning. Science 196:161-169.

5. Celander, D., and W. A. Haseltine. 1984. Tissue-specific transcription preference as a determinant of cell tropism and leukaemogenic potential of murine retroviruses. Nature (London) 312:159-162

6. Chen, I. S. Y., J. McLaughlin, and D. W. Golde. 1984. Long terminal repeats of human $\mathrm{T}$-cell leukemia virus II genome determine target cell specificity. Nature (London) 309:276-279.

7. Dalgleish, A. G., P. C. L. Beverley, P. R. Clapham, D. H. Crawford, M. F. Greaves, and R. A. Weiss. 1984. The CD4(T4) antigen is an essential component of the receptor for the AIDS retrovirus. Nature (London) 312:763-767.

8. Folks, T., S. Benn, A. Rabson, T. Theodore, M. D. Hoggan, M. Martin, M. Lightfoote, and K. Sell. 1985. Characterization of a continuous T-cell line susceptible to the cytopathic effects of the acquired immunodeficiency syndrome (AIDS)-associated retrovirus. Proc. Natl. Acad. Sci. USA 82:4539-4543.

9. Gallo, R. C., S. Z. Salahuddin, M. Popovic, G. M. Shearer, M. Kaplan, B. F. Haynes, T. J. Palker, R. Redfield, J. Oleske, B. Safai, G. White, P. Foster, and P. D. Markham. 1984. Frequent detection and isolation of cytopathic retroviruses (HTLV-III) from patients with AIDS and at risk for AIDS. Science 224:500-503.

10. Gendelman, H. E., T. R. Moench, O. Narayan, and D. E. Grifin. 1983. Selection of a fixative for identifying $T$ cell subsets, B cells, and macrophages in paraffin-embedded mouse spleen. $J$. Immunol. Methods 65:137-145.

11. Gendelman, H. E., O. Narayan, S. Molineaux, J. E. Clements, and Z. Ghotbi. 1985. Slow, persistent replication of lentiviruses: role of tissue macrophages and macrophage precursors in bone marrow. Proc. Natl. Acad. Sci. USA 82:7086-7090.

12. Gluzman, Y. 1981. SV40-transformed simian cells support the replication of early SV40 mutants. Cell 23:175-182.

13. Gorman, C. M., L. F. Mofiat, and B. H. Howard. 1982. Recombinant genomes which express chloramphenicol acetyltransferase in mammalian cells. Mol. Cell. Biol. 2:1044-1051.

14. Gottlieb, M. S., J. E. Groopman, W. M. Weinstein, J. L. Fahey, and R. Detels. 1983. The acquired immunodeficiency syndrome. Ann. Intern. Med. 99:208-220.
15. Gottlieb, M. S., R. Schroff, H. M. Schanker, J. D. Weisman, P. T. Fan, R. A. Wolf, and A. Saxon. 1981. Pneumocystis carinii pneumonia and mucosal candidiasis in previously healthy homosexual men: evidence of a new acquired cellular immunodeficiency. N. Engl. J. Med. 305:1425-1431.

16. Graham, F. L., and A. J. Van der Eb. 1973. A new technique for the assay of infectivity of human adenovirus 5 DNA. Virology 52:456-467.

17. Hahn, B. H., M. A. Gonda, G. M. Shaw, M. Popovic, J. A. Hoxie, R. C. Gallo, and F. Wong-Staal. 1985. Genomic diversity of the acquired immune deficiency syndrome virus HTLV-III: different viruses exhibit greatest divergence in their envelope genes. Proc. Natl. Acad. Sci. USA 82:4813-4817.

18. Hopkins, N., J. Schindler, and P. D. Gottlieb. 1977. Evidence for recombination between $\mathrm{N}$ - and $\mathrm{B}$-tropic murine leukemia viruses. J. Virol. 21:1074-1078.

19. Hopkins, N., J. Schindler, and R. Hynes. 1977. Six NB-tropic murine leukemia viruses derived from a B-tropic virus of BALB/c have altered p30. J. Virol. 21:309-318.

20. Klatzmann, D., F. Barre-Sinoussi, M. T. Nugeryre, C. Daugnet, E. Vilmer, C. Griscelli, F. Brun-Vezinet, C. Rouzioux, J. C. Gluckman, J. C. Chermann, and L. Montagnier. 1984. Selective tropism of lymphadenopathy associated virus (LAV) for helperinducer T-lymphocytes. Science 255:59-63.

21. Klatzman, D., E. Champagne, S. Chamaret, J. Gruest, D. Guetard, T. Hercend, J. C. Gluckmann, and L. Montagnier. 1984. T-lymphocyte T4 molecule behaves as the receptor for human retrovirus LAV. Nature (London) 312:767-770.

22. Klein, G., T. Lindahl, M. Jondal, W. Leibold, J. Menezes, K. Nilsson, and C. Sundstrome. 1974. Continuous lymphoid cell lines with B-cell characteristics that lack the Epstein-Barr virus genome, derived from three human lymphomas. Proc. Natl. Acad. Sci. USA 71:3283-3286.

23. Levy, J. A., A. D. Hofiman, S. M. Kramer, J. A. Lanois, J. M. Shimabukuro, and L. S. Oskiro. 1984. Isolation of lymphocytopathic retroviruses from San Francisco patients with AIDS. Science 225:840-842.

24. Levy, J. A., J. Shimabukuro, T. McHugh, C. Casavant, D. Stites, and L. Oshiro. 1985. AIDS-associated retroviruses (ARV) can productively infect other cells besides human $\mathrm{T}$ helper cells. Virology 147:441-448.

25. Luciw, P. A., S. J. Potter, K. Steimer, D. Dina, and J. A. Levy. 1984. Molecular cloning of AIDS-associated retrovirus. Nature (London) 312:760-763.

26. McDougal, J. S., M. S. Kennedy, J. N. Sligh, S. P. Cort, A. Mawle, and J. K. A. Nicholson. 1985. Binding of HTLV-III/LAV to $\mathrm{T}^{+} \mathrm{T}$ cells by a complex of the $110 \mathrm{~K}$ viral protein and the $\mathrm{T} 4$ molecule. Science 231:382-385.

27. Montagnier, L., J. Gruest, S. Chamaret, C. Dauguet, C. Axler, C. Guetard, M. T. Nugeryre, F. Barre-Sinoussi, J. C. Chermann, J. B. Brunt, D. Klatzman, and J. C. Gluckman. 1984. Adaptation of lymphadenopathy-associated virus (LAV) to replication in EBV-transformed B lymphoblastoid cell lines. Science 225:63-66.

28. Mullins, J. I., D. S. Brody, R. C. Binari, Jr., and S. M. Cotter. 1984. Viral transduction of $c-m y c$ gene in naturally occurring feline leukaemias. Nature (London) 308:856-858.

29. Pincus, T., J. W. Hartley, and W. P. Rowe. 1971. A major genetic locus affecting resistance to infection with murine leukemia viruses. I. Tissue culture studies of naturally occurring viruses. J. Exp. Med. 133:1219-1223

30. Potter, H., W. Lawrence, and P. Leder. 1984. Enhancerdependent expression of human $\mathrm{K}$ immunoglobulin genes introduced into mouse pre-B lymphocytes by electroporation. Proc. Natl. Acad. Sci. USA 81:7161-7165.

31. Schlindler, J., R. Hynes, and N. Hopkins. 1977. Evidence for recombination between $\mathrm{N}$ - and $\mathrm{B}$-tropic murine leukemia viruses: analysis of three virion proteins by sodium dodecyl sulfate-polyacrylamide gel electrophoresis. J. Virol. 23:700-707.

32. Shaw, G. M., B. H. Hahn, S. K. Arya, J. E. Groupmann, R. C. Gallo, and F. Wong-Staal. 1984. Molecular characterization of human T-cell leukemia (lymphotropic) virus type III in the acquired immune deficiency syndrome. Science 226:1165-1171. 
33. Sodroski, J., R. Patarca, C. A. Rosen, F. Wong-Staal, and W. A. Haseltine. 1985. Location of the trans-activating region of the genome of human T-cell lymphotropic virus type III. Science 229:74-77.

34. Sonigo, P., M. Alizon, K. Staskus, D. Klatzmann, S. Cole, O. Danos, E. Retzel, P. Tiollais, A. Haase, and S. Wain-Hobson. 1985. Nucleotide sequence of the visna lentivirus: relationship to the AIDS virus. Cell 42:369-382.

35. Southern, P. J., and P. Berg. 1982. Transformation of mammalian cells to antibiotic resistance with a bacterial gene under control of the SV40 early region promoter. J. Mol. Appl. Genet. $1: 327-341$.

36. Weiss, R. 1982. Experimental biology and assay of RNA tumor viruses, p. 209-260. In R. Weiss, N. Teich, H. Varmus, and J.
Coffin (ed.), RNA tumor viruses. Cold Spring Harbor Laboratory, Cold Spring Harbor, N.Y.

37. Wigler, M., A. Pellicer, S. Silverstein, R. Axel, G. Urlaub, and L. Chasin. 1979. DNA-mediated transfer of the adenine phosphoribosyltransferase locus into mammalian cells. Proc. Natl. Acad. Sci. USA 76:1373-1376.

38. Wong-Staal, F., G. M. Shaw, B. H. Hahn, S. Z. Salahuddin, M. Popovic, P. Markham, R. Redfield, and R. C. Gallo. 1985. Genomic diversity of human T-lymphotropic virus type III (HTLV-III). Science 229:759-762.

39. Zavada, J., Z. Zavadova, G. Russ, K. Polakova, J. Rajcani, J. Stencl, and J. Loksa. 1983. Human cell surface proteins selectively assembled into vesicular stomatitis virus virions. Virology 127:345-360. 